\title{
THE EVALUATION OF THE COMPATIBILITY OF CEREAL AND GREEN MANURE ON THE BASIS OF NUTRIENTS
}

Aušra ARLAUSKIENĖ, Joniškèlis Experimental Station of the Lithuanian Research Centre for Agriculture and Forestry, Joniškèlis, Pasvalys distr., Lithuania, arlauskiene.ausra@gmail.com

Viktorija GECAITE், Joniškèlis Experimental Station of the Lithuanian Research Centre for Agriculture and Forestry, Joniškèlis, Pasvalys distr., Lithuania, viktorija.gecaitegmail.com (corresponding author)

Danutė JABLONSKYTÉ-RAŠČÉ, Joniškèlis Experimental Station of the Lithuanian Research Centre for Agriculture and Forestry, Joniškèlis, Pasvalys distr., Lithuania, viktorija.gecaitegmail.com

Research was carried out at the Lithuanian Research Centre for Agriculture and Forestry's (LAMMC) Joniškèlis Experimental Station on a clay loam Endocalcari Endohypogleyic Cambisol. The study was aimed to explore the aboveground mass of perennial forage legumes: red clover (Trifolium pratense L.) and lucerne (Medicago sativa L.), and their mixtures with festulolium (x Festuliolium), used as green manure, qualitative parameters and compatibility with cereals on the basis of nutrients nitrogen $(\mathrm{N})$, phosphorus $(\mathrm{P})$ and potassium $(\mathrm{K})$. The deficiency of other nutrients $(\mathrm{P}, \mathrm{K})$ and intensity of green manure mineralization can lead to $\mathrm{N}$ absorption. It has been determined that winter wheat takes one $\mathrm{kg}$ of $\mathrm{N}$ together with $0.2 \mathrm{~kg} \mathrm{P}$ and $0.6 \mathrm{~kg} \mathrm{~K}$. Spring wheat requires a similar amount of $\mathrm{P}$ but a higher amount of K. Average winter wheat grain yield can be $4.0 \mathrm{t} \mathrm{ha}^{-1}$ on a clay loam Cambisol in organic cropping system. NPK content $-134 \mathrm{~kg} \mathrm{ha}^{-1}$ is needed for such productivity (grain + straw). This content is lower for spring winter growing. P:N and $\mathrm{K}: \mathrm{N}$ ratios are more favourable in perennial forage legume mixture with festulolium, as compared to legume alone. To obtain grain yields of $4 \mathrm{t} \mathrm{ha}^{-1}$ of winter wheat and $3 \mathrm{t} \mathrm{ha}^{-1}$ of spring wheat in balanced organic crop rotation it is sufficient to apply 3.0 and $2.0 \mathrm{t} \mathrm{ha}^{-1} \mathrm{DM}$ of pure legume mass as green manure. "Cut-and-carry" fertilisers do not satisfy the wheat demand for P.

Keywords: green manure, nitrogen, organic farming, phosphorus, potassium, yields of cereals.

\section{INTRODUCTION}

A wide variety of means for maintaining and improving soil fertility and crop productivity are applied in organic farming. Biologically fixed nitrogen (BFN) accumulated in the biomass of legume is one of the most important and cheapest sources for supplying rotating plants with nitrogen (N) (Kadžiulienè et al., 2013; Zotarelli et al., 2012). Lately, much attention is devoted to forage legumes both as a source of BFN and as a soil fertility-building crop (ThorupKristensen et al., 2012). The roots of legumes are well developed; therefore, they penetrate deep into the subsoil. There they break down the nutrients hardly available for other plants and accumulate them in plant biomass and topsoil. It is suggested, that the subsoil can contribute to more than two-thirds of the plant nutrition of N, P and K, especially when the topsoil is dry or nutrient-depleted (Kautz et al., 2013).

For cereals, $\mathrm{N}$ is necessary throughout the whole period of their vegetation. However, at different development stages the effect of $\mathrm{N}$ on the formation of grain yield varies (Diekmann and Fishbeck, 2005). Until now, little attention has been paid to the compatibility of cereal needs and fertilisation with green manure. The majority of research was based on the grounds that Poaceous cereal crops used BFN indirectly, that is, only after forage legumes have been ploughed up. Thus, a high $\mathrm{N}$ content is incorporated at the same time; therefore, it is not always possible to control the intensity of the mineralisation potential, $\mathrm{N}$ flows and efficiency of application. Most often, winter cereals were fertilised with green manure of legumes in autumn. On the one hand, growing forage legumes during the entire growing season helps accumulating large quantities of organic matter, BFN, $\mathrm{P}$ and $\mathrm{K}$; on the other hand, having incorporated this mass in autumn we are not able to handle these flows of organic matter and plant available nutrient movement. It is suggested, that some part of green manure of legumes can be transported and used in a different field - using a "cut-and-carry" fertilisation system. Van der Burgt et al. (2013) propose that the "cut-and-carry" fertilisers are a serious alternative for manure as a part of an overall strategy. The green mass of plants can be used as manure for spring or winter cereals during the first half of the growing season. "Cut-and-carry" fertilisers have a lot of advantages: it is easier to balance NPK and sulfur (S) needs by plants and avoid surplus fertilisation; it is also easier to control N release and losses. It is proposed, that deficiency of at least one specific nutrient could block the assimilation of other nutrients (Bagdoniene et al., 1999).

Copyright (C) 2017 The Authors. Published by Aleksandras Stulginskis University. This is an open-access article distributed under the terms of the Creative Commons Attribution License (CC-BY 4.0), which permits unrestricted use, distribution, and reproduction in any medium, provided the original author and source are credited. 
The possibilities of applying "cut-and-carry" fertilisers are broader: you can select the most appropriate fertiliser rate, fertilisation time can be adjusted to the needs of cultivated plants, and the most appropriate methods of incorporation and mulching can be applied. This is important due to the fact that the efficiency of plant available nutrients is determined by factors that are independent of human activities, i. e. soil properties and meteorological conditions. The purpose of the research was to evaluate qualitative parameters of the aboveground mass of different perennial forage crops and their compatibility in terms of NPK for fertilisation of winter and spring wheat using the "cut-and-carry" fertilisation system.

\section{MATERIALS AND METHODS}

Field experiments were conducted at the Joniškèlis Experimental Station of the Lithuanian Research Centre for Agriculture and Forestry's (geographical coordinates $56^{\circ} 12^{\prime} \mathrm{N}, 24^{\circ} 20^{\prime} \mathrm{E}$ ) in $2009-2010$ and 2015-2016. The soil of the experimental site is a limnoglacial Endocalcaric Endogleyic Cambisol (Siltic, Drainic). The soil texture is clay loam (at a depth of 0-25 cm) on silty clay (at a depth of 26-76 cm) with deeper lying sandy loam (at a depth of 77-135 cm).The soil was moderate in $\mathrm{P}-142 \mathrm{mg} \mathrm{kg}^{-1} \mathrm{P}_{2} \mathrm{O}_{5}$ and high in $\mathrm{K}-223 \mathrm{mg} \mathrm{kg}^{-1} \mathrm{~K}_{2} \mathrm{O}$, with $\mathrm{N}_{\text {tot. }}$ of $0.126 \%$, $\mathrm{C}_{\text {org. }}$. of $1.67 \%$. Lithuania has a climate mid-way between maritime and continental.

In assessing the compatibility of wheat with green manure the data from the following experiments was used: "Optimisation of nitrogen cycling by using forage legumes as green manure in the organic agrosystem" (Mulch Experiment) and "Influence of biological and organic fertiliser nitrogen on spring cereal productivity and quality under organic agriculture conditions" (Biological and organic N Experiment). In the case of mulch experiment, the qualitative indicators of the aboveground mass of perennial grasses: festulolium (Festulolium L.), red clover (Trifolium pretence L.) mixture of red clover and festulolium, lucerne (Medicago sativa L.), mixture of lucerne and festulolium were evaluated. $\mathrm{N}, \mathrm{P}, \mathrm{K}$ accumulated in winter and spring cereals was established in the biological and organic $\mathrm{N}$ experiment. On the basis of this data, a theoretical quantity of different legumes or legume and grass mixture mass and the probability to cover nutrients accumulated in the yield of winter wheat $\left(4 \mathrm{tha}^{-1}\right)$ and spring wheat $\left(3 \mathrm{tha}^{-1}\right)$ were calculated.

In 2009 of establishment of Mulch experiments, spring barley (variety 'Ula') was undersown with perennial grasses: festulolium variety 'Punia' at a seed rate of 6.2 million ha $^{-1}$, red clover variety 'Vyliai' at a seed rate 7.5 million ha $^{-1}$, lucerne variety 'Birute' at seed rate of 7.5 million $\mathrm{ha}^{-1}$, and mixtures of forage legumes with festulollium (seed rate legume to grass 2:1). In 2010 perennial grasses were cut for green manure at the bud formation stage. In the biological and organic $\mathrm{N}$ experiment winter wheat variety 'Ada' at a seed rate of 5.5 million ha $^{-1}$ and spring wheat variety 'Vanek' at a seed rate of 4.5 million $\mathrm{ha}^{-1}$ were grown according to the organic farming standards. The aboveground mass of perennial grasses of each cut were measured by weighing. The straw yield of the wheat in the hard wax maturity stage was established in 4 spots of 0.25 $\mathrm{m}^{2}$ and samples for analyses were taken. The wheat grain was harvested by a mini combine harvester. One kg samples of grain were taken at harvesting for the determination of dry matter and chemical composition. The aboveground mass of perennial grasses, wheat straw and grain were analysed for: N, P, K (spectrophotometer UV/VIS Cary 50 and an atomic absorptiometer AANALYST 200 respectively) and carbon (C) (Dumas method) only for forage legumes and their mixture with festulolium.

Perennial grasses, winter and spring wheat were grown in $16 \times 5=80 \mathrm{~m}^{2}$ plots, with 4 replicationsin a randomised order. The variations of the data were estimated by the standard deviation $( \pm \mathrm{SD})$ at the significance level $\mathrm{P}<0.05$. All statistical analyses were performed using the SELEKCIJA software package, STAT_ENG program vers. 1.55 (Tarakanovas and Raudonius, 2003).

\section{RESULTS AND DISCUSSION}

Nutrient $(\mathrm{N}, \mathrm{P}, \mathrm{K})$ needs to produce one tonne of winter and spring wheat depend on biological characteristics of plants, mobility of soil nutrients and meteorological conditions during the key stages of plant growth and development. Wheat is a crop, which favours $\mathrm{N}$ : they need 4.0-4.2 times more $\mathrm{N}$ compared to $\mathrm{P}$ and $1.8-2.6$ times more than $\mathrm{K}$. Wheat accumulates the major amount of $\mathrm{N}$ and $\mathrm{P}$ in grain. Distribution of $\mathrm{P}$ in parts of a plant is analogous to that of $\mathrm{N}$ and they are closely linked. Compared to other plants, cereals do not require much K. As a rule, cereals accumulate $\mathrm{K}$ in their vegetative parts - straw. The use of straw as a fertiliser results in returning $\mathrm{K}$ back into soil. The comparison between winter and spring wheat demonstrated that winter crops accumulated higher contents of $\mathrm{K}$ compared to spring crops. This may be related to winter crop resistance to low temperatures. Winter wheat consumes one and a half times higher $\mathrm{K}$ per kilogram of $\mathrm{N}$ compared to spring wheat. In this regard, P:N ratio values are less coherent.

Table 1. Winter and spring wheat demand for nitrogen, phosphorus and potassium

\begin{tabular}{|c|c|c|c|c|c|c|}
\hline \multirow{2}{*}{ Crops } & \multirow{2}{*}{$\begin{array}{c}\text { Type of } \\
\text { production }\end{array}$} & \multicolumn{2}{|c|}{ Nutrients accumulated in 1t of production kg \pm SD } & \multirow{2}{*}{ P:N } & \multirow{2}{*}{ K:N } \\
\cline { 3 - 5 } & grain & $15.0 \pm 0.11$ & $4.0 \pm 0.04$ & $3.8 \pm 0.38$ & $0.27 \pm 0.00$ & $0.26 \pm 0.03$ \\
\hline \multirow{3}{*}{$\begin{array}{c}\text { Spring } \\
\text { wheat }\end{array}$} & straw & $3.2 \pm 0.04$ & $0.5 \pm 0.01$ & $3.1 \pm 0.04$ & $0.16 \pm 0.01$ & $0.96 \pm 0.01$ \\
\cline { 2 - 6 } & total & $18.2 \pm 0.13$ & $4.5 \pm 0.04$ & $6.9 \pm 0.36$ & $0.25 \pm 0.00$ & $0.38 \pm 0.02$ \\
\hline \multirow{3}{*}{$\begin{array}{c}\text { Winter } \\
\text { wheat }\end{array}$} & grain & $15.6 \pm 0.26$ & $3.4 \pm 0.05$ & $4.7 \pm 0.07$ & $0.22 \pm 0.01$ & $0.30 \pm 0.01$ \\
\cline { 2 - 6 } & straw & $3.0 \pm 0.06$ & $1.0 \pm 0.03$ & $5.7 \pm 0.12$ & $0.33 \pm 0.01$ & $1.91 \pm 0.05$ \\
\cline { 2 - 6 } & total* & $18.6 \pm 0.26$ & $4.4 \pm 0.05$ & $10.4 \pm 0.14$ & $0.24 \pm 0.01$ & $0.56 \pm 0.10$ \\
\hline
\end{tabular}

Notes. $*$ grain yield : straw yield $=1 ; \pm \mathrm{SD}-$ standard deviation 
On farm BFN is a driving force in organic agriculture. The efficiency with which this $\mathrm{N}$ is used can be increased by using lucerne, red clover or legume-grass forage crops directly as a fertiliser and on other fields as cut-and-carry fertilisers. The studies showed that the maximum $\mathrm{N}$ content was present in one tonne of DM of the aboveground mass of pure legume (Table 2). Lucerne accumulated higher quantities of $\mathrm{N}\left(2.3 \mathrm{~kg} \mathrm{t}^{-1}\right.$ on average) compared to red clover. Growing of forage legumes with festulolium resulted in a marginal decrease of $\mathrm{N}$ content in the aboveground mass (7.0$8.0 \mathrm{~kg} \mathrm{t}^{-1} \mathrm{DM}$ ) compared with pure legume. As compared to wheat, perennial grasses accumulated more $\mathrm{N}$ and $\mathrm{K}$ in one tonne of the aboveground mass DM and marginally lower quantities of $\mathrm{P}$. In contrast to $\mathrm{N}$, the aboveground mass of all legumes and their mixtures with festulolium accumulated lower quantities of $\mathrm{P}$ with the exception of pure festulolium. Therefore, growing legumes in mixtures with festulolium demonstrated a tendency of increasing the accumulated $\mathrm{P}$ content. Lucerne accumulated insignificantly higher content of $\mathrm{P}$ compared to red clover. Literature references indicate that due to lucerne strong root systems can dissolve hardly soluble P compounds (Van der Burgt et al., 2013). The aboveground mass of legumes and their mixtures with festulolium accumulated high contents of $\mathrm{K}\left(27.0-28.5 \mathrm{~kg} \mathrm{t}^{-1} \mathrm{DM}\right)$. There were no significant differences between grass types. K:N values between the types of grasses varied. K:N indicator values of festulolium or its mixtures with legumes were determined by a lower content of BFN. Those indicators of wheat were 1.4-2.6 times lower. The comparison of green manure and cattle manure in terms of the accumulated $\mathrm{N}$ revealed that the aboveground mass of legumes is richer, and the mixture of legumes and festulolium equals to manure. However, animal manure is superior to green manure in terms of the accumulated contents of $\mathrm{K}$ and especially that of $\mathrm{P}$.

Table 2. Content of nutrients accumulated in aboveground mass of perennial grasses and cattle manure

\begin{tabular}{|c|c|c|c|c|c|c|}
\hline \multirow{2}{*}{$\begin{array}{l}\text { Perennial forage } \\
\text { crops }\end{array}$} & \multicolumn{3}{|c|}{$\mathrm{kg} \mathrm{t}^{-1} \mathrm{DM}$} & \multirow{2}{*}{$P: N$} & \multirow{2}{*}{$\mathrm{K}: \mathrm{N}$} & \multirow[b]{2}{*}{$\mathrm{C}: \mathrm{N}$} \\
\hline & $\mathrm{N}$ & $\mathrm{P}$ & $\mathrm{K}$ & & & \\
\hline Festulolium & $16.0 \pm 1.9$ & $4.1 \pm 0.4$ & $27.0 \pm 2.3$ & $0.26 \pm 0.01$ & $1.76 \pm 0.10$ & $34.5 \pm 3.87$ \\
\hline Red clover & $33.2 \pm 0.4$ & $3.3 \pm 0.1$ & $28.5 \pm 1.7$ & $0.10 \pm 0.00$ & $0.86 \pm 0.04$ & $16.0 \pm 0.19$ \\
\hline $\begin{array}{l}\text { Red clover and } \\
\text { festulolium }\end{array}$ & $27.4 \pm 1.2$ & $3.5 \pm 0.7$ & $27.8 \pm 0.3$ & $0.13 \pm 0.01$ & $1.04 \pm 0.06$ & $19.4 \pm 0.95$ \\
\hline Liucerne & $35.5 \pm 0.8$ & $3.7 \pm 0.1$ & $27.3 \pm 2.1$ & $0.10 \pm 0.00$ & $0.78 \pm 0.03$ & $14.8 \pm 0.27$ \\
\hline $\begin{array}{l}\text { Liucerne and } \\
\text { festulolium }\end{array}$ & $28.5 \pm 2.6$ & $3.6 \pm 0.2$ & $27.3 \pm 0.7$ & $0.13 \pm 0.01$ & $1.03 \pm 0.09$ & $19.8 \pm 2.11$ \\
\hline Cattle manure & 27.6 & 13.4 & 54.4 & 0.49 & 1.97 & 17.0 \\
\hline
\end{tabular}

Note. \pm SD - standard deviation

$\mathrm{N}$ and $\mathrm{P}$ are present in the organic compounds within plant mass. These nutrients can be available to plants only when they are released from green manure and enter the soil. It depends on the intensity of green manure mineralisation or $\mathrm{C}$ and $\mathrm{N}$ ratio $(\mathrm{C}: \mathrm{N})$. A narrow $\mathrm{C}: \mathrm{N}$ ratio indicates that pure legume mass starts to decompose first. This kind of manure has the largest content of organic compounds rich in $\mathrm{N}$ and easily decomposable by microorganisms (Fuchs et al., 2009). Growing legumes in mixtures with grasses (festulolium) results in widening the C:N ratio and decreasing decomposition intensity. It was established that, during the growing period about $50 \%$ of incorporated legume mass is decomposed (Henriksen and Breland, 1999). Another part of the manure, which consists of more stable organic compounds, is decomposed more slowly, and intermediate decomposition products are used for the synthesis of soil humic substances. $\mathrm{N}$ present in green manure is incorporated into the composition of more stable soil organic compounds and later becomes plant available. $\mathrm{K}$ is mostly found in mineral form. The studies showed that within the first month after plant mass utilisation $\mathrm{K}$ is leached into the soil (Arlauskiené et al., 2016). In terms of mineralisation intensity cattle manure exceeds the mass of mixtures composed of legumes and festulolium, however, it concedes to that of lucerne. Organic manure decomposition depends on the intensity of productive soil moisture reserves, temperature (Kuang et al., 2014), microbial community (Henriksen and Breland, 1999) and green manure particle size. Therefore, the release of the main nutrients from green manure is not constant - it depends on many factors.

Demand for green manure (rate $\mathrm{tha}^{-1}$ ) depends on the type of cereals grown and the yield planned. It is determined based on $\mathrm{N}$ need, which determines the assimilation of other nutrients ( $\mathrm{P}$ and $\mathrm{K}$ ) as well. An organic farming system applied on clay loam Cambisol can yield $4.0 \mathrm{t} \mathrm{ha}^{-1}$ of winter wheat and $3.0 \mathrm{t} \mathrm{ha}^{-1}$ of spring wheat (Masilionyte et al., 2011; Nemeikšienè et al., 2010). To obtain such yields $74.4 \mathrm{~kg} \mathrm{ha}^{-1} \mathrm{~N}$ and $54.6 \mathrm{~kg} \mathrm{ha}^{-1} \mathrm{~N}$ are required respectively (Figure 1a). $\mathrm{N}$ demand for winter wheat ( $4 \mathrm{t} \mathrm{ha}^{-1}$ for grain harvest) corresponds to $\mathrm{N}$ content accumulated in $3.0 \mathrm{t} \mathrm{ha}^{-1} \mathrm{mass}$ of red clover and lucerne. For the fertilisation of spring wheat $2 \mathrm{t} \mathrm{ha}^{-1}$ mass of red clover and lucerne is sufficient. If the mass of forage legumes and festulolium mixtures is applied the fertiliser rate should be increased by $0.5-1.0 \mathrm{tha}^{-1} \mathrm{DM}$.

$\mathrm{P}$ content accumulated in green manure is too low to obtain the planned grain yields of winter and spring wheat (Figure 1b). Therefore, abundant application of green manure can result in the decrease of $\mathrm{P}$ content in the soil and pose one of possible plant nutrition problems (Lynch, 2015). Finite resources such as P "cut-and-carry" fertilisers should be combined with P mineral fertilisers of natural origin. Such soils are better suited for cultivating perennial legumes compared to bringing green mass from another field. While choosing the type of grasses to be grown, it is expedient to cultivate forage legumes mixtures with an increased proportion of festulolium. In addition, it is worth choosing such legumes and festulolium types that have a characteristic of breaking down hardly available hard $\mathrm{P}$ compounds. Taproot systems of perennial legumes can make soil nutrients plant available from the solid phase and increase the density of vertical biopores in the subsoil thus making subsoil layers more accessible for succeeding crops (Köpke et al., 2015). 
a)

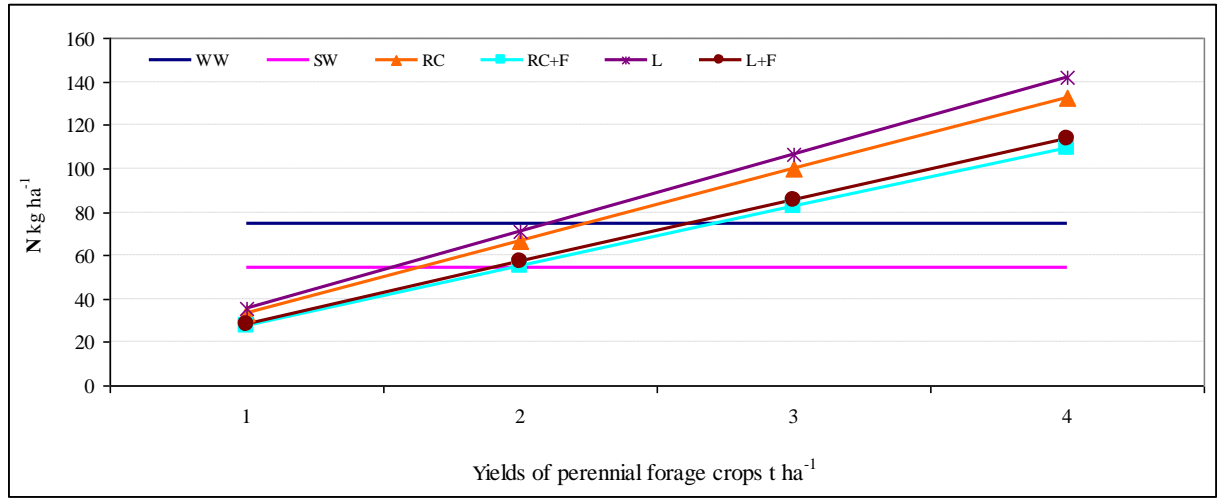

b)

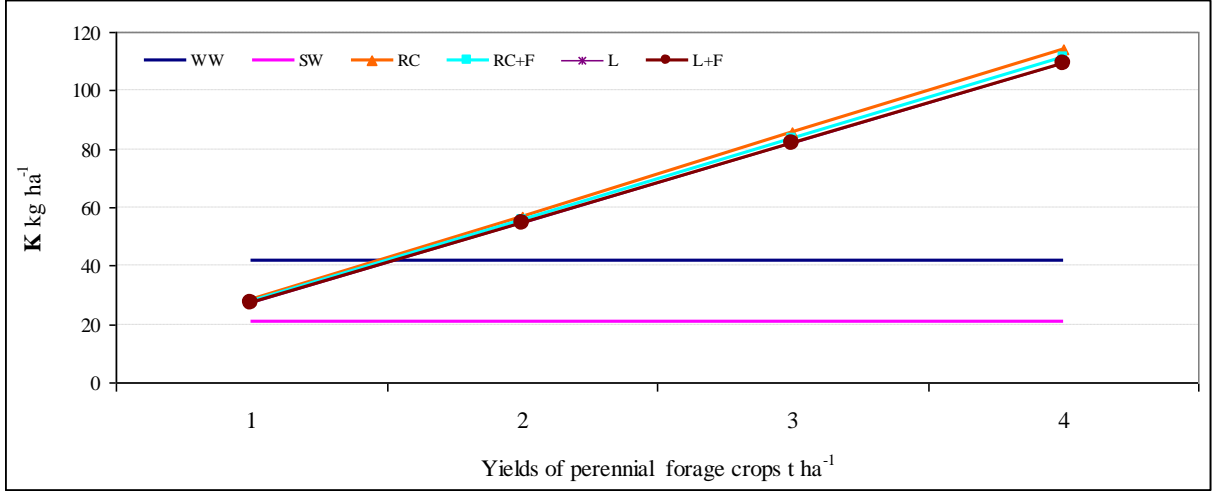

c)

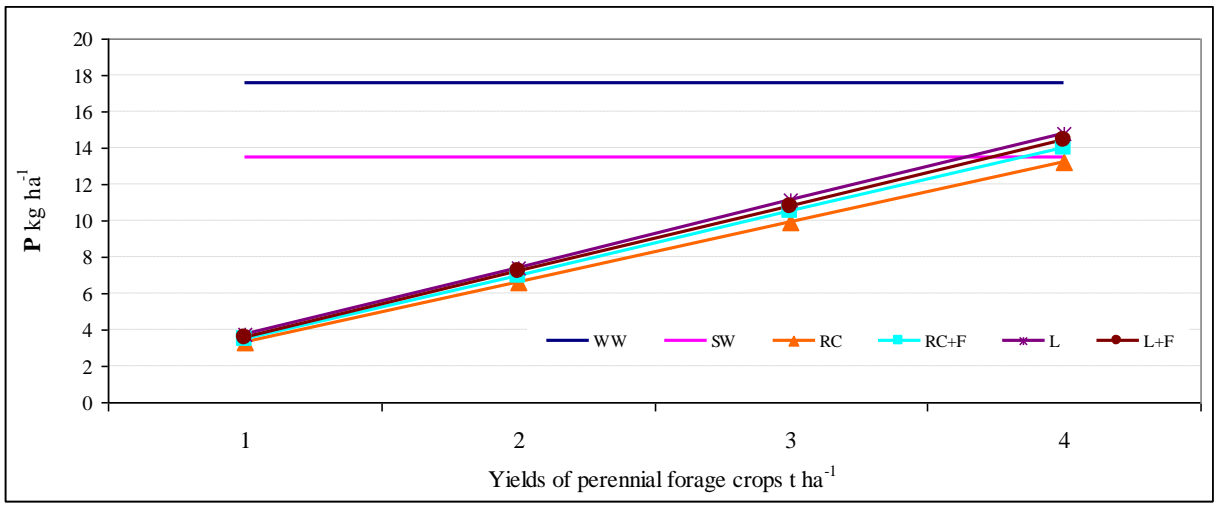

Figure 1. Demand for nutrients N (a), P (b) and K (c) to obtain yields of winter wheat $\left(4 \mathrm{tha}^{-1}\right)$ and spring wheat $\left(3 \mathrm{tha} \mathrm{a}^{-1}\right)$ Note. WW- winter wheat; SW - spring wheat; RC - red clover; RC+F - red clover and festulolium; L - lucerne; L+F - lucerne and festulolium.

Fertilisation of wheat with green manure (regardless of its type) according to $\mathrm{N}$ need fully satisfies demand for $\mathrm{K}$ (Figure 1c). It was found that surplus $\mathrm{K}$ could block the assimilation of other nutrients sodium ( $\mathrm{Na})$, calcium $(\mathrm{Ca})$, magnesium $(\mathrm{Mg})$.

Plants assimilate nutrients not only from fertilisers applied, but a considerable portion is also taken from the soil. Therefore, "cut-and-carry" fertilisers are expedient to be used in fully nutrient balanced organic crop rotation. Janssen (1998) proposed that nutrient uptake efficiency, i.e. the ratio of actual uptake to potential supply, and utilisation efficiency, i.e. the ratio of yield to actual uptake, require $\mathrm{N}, \mathrm{P}$ and $\mathrm{K}$ perfectly in balance to reach their maximum values.

\section{CONCLUSIONS}

1. The essential nutrient in organic winter and spring wheat cultivation is $\mathrm{N}$, demand for which equals to $18.2-18.6 \mathrm{~kg}$ $\mathrm{t}^{-1}$ to obtain grain and straw yields. It is 4.0-4.2 times more compared to P and 1.8-2.6 times more than $\mathrm{K}$. Winter wheat requires more $\mathrm{K}$ compared to spring wheat.

2. Red clover, lucerne and its mixtures with festulolium accumulated high content of $\mathrm{N}\left(27.4-35.5 \mathrm{~kg} \mathrm{t}^{-1} \mathrm{DM}\right)$ and $\mathrm{K}$ (27.3-28.5 $\left.\mathrm{kg} \mathrm{t}^{-1} \mathrm{DM}\right)$ and low content of $\mathrm{P}\left(3.3-3.7 \mathrm{~kg} \mathrm{t}^{-1} \mathrm{DM}\right)$ in the aboveground mass. The release of these nutrients from green manure depends on the intensity of their decomposition ( $\mathrm{C}$ and $\mathrm{N}$ ratio). In terms of the rate of nutrient release, the plants used as green manure are ranged in the following order: lucerne > red clover $>$ mixture of lucerne and festulolium/of red clover and festulolium > festulolium. 
3. To obtain grain yields of $4 \mathrm{t} \mathrm{ha}^{-1}$ of winter wheat and $3 \mathrm{tha}^{-1}$ of spring wheat in balanced organic crop rotation it is sufficient to apply 3.0 and $2.0 \mathrm{t} \mathrm{ha}^{-1} \mathrm{DM}$ of pure legume mass as green manure. Using forage legumes and festulolium mixtures as fertilisers the fertilisation rate should be increased to $0.5-1.0 \mathrm{t} \mathrm{ha}^{-1} \mathrm{DM}$. These green manure rates correspond to the demand for $\mathrm{N}$ and $\mathrm{K}$ by winter and spring wheat. "Cut-and-carry" fertilisers do not satisfy the wheat demand for P.

\section{REFERENCES}

1. Arlauskienè, A., Velykis, A., Šlepetienė, A., Janušauskaitè, D. 2016. Comparison of postharvest practices used for cereal straw decomposition in a clay loam soil. Acta Agriculturae Scandinavica, Section B. Soil \& Plant Science, Vol.66, Iss. 6, pp. 523-533.

2. Bagdoniene, V., Arlauskiené, E.A. 1999. The influence of available phosphorus content in the soil and mineral fertilizer application on the crop yield, on biological activity in a crop rotation. Agriculture, Vol. 65, pp. 48-62.

3. Diekmann, F., Fishbeck, G. 2005. Differences in wheat cultivar response to nitrogen supply. II: differences in N-metabolism related traits. Journal of Agronomy and Crop Science, Vol. 191, pp. 362-376. https://doi.org/10.1111/j.1439-037X.2005.00166.x

4. Fuchs, J.G., Schleiss, K. 2009. Effects of compost and digestate on the environment, soil fertility, and plant health: ecological assessment of organic matter. Final Report. - 37 p., FiBL Switzerland.

5. Henriksen, T.M, Breland, T.A. 1999. Decomposition of crop residues in the field: evaluation of a simulation model developed from microcosm studies. Soil Biology and Biochemistry, Vol. 31, pp. 1423-1434. https://doi.org/10.1016/S0038-0717(99)00063-2

6. Janssen, B. H. 1998. Efficient use of nutrients: an art of balancing. Field Crops Research, Vol. 56, pp. 197-201. https://doi.org/10.1016/S0378-4290(97)00130-5

7. Kadžiulienè, Ž., Šarūnaite, L., Kadžiulis, L. 2013. The impact of nitrogen in red clover and Lucerne swards on the subsequent spring wheat. Organic systems as a driver for change. NJR Report (NJF seminar 461), Vol. 9, No. 3, pp. 159-160, Bredstend, Denmark.

8. Kautz, T., Amelung, W., Ewert, F. et al. 2013. Nutrient acquisition from arable subsoils in temperate climates: A review. Soil Biology \& Biochemistry, Vol. 57, pp. 1003-1022. https://doi.org/10.1016/j.soilbio.2012.09.014

9. Köpke, U., Athmann, M., Han, E., Kautz, T. 2015. Optimising Cropping Techniques for Nutrient and Environmental Management in Organic Agriculture. Sustainable Agriculture Research, Vol. 4, No. 3, pp.15-25. https://doi.org/10.5539/sar.v4n3p15

10. Kuang, E., Chi, F., Jeng, A.S., Zhang, J. 2014. A comparison of different methods of decomposing maize straw in China. Acta Agriculturea Scandinavica, Section B - Soil \& Plant Science, Vol. 63, Iss. 2, pp. 186-194.

11. Lynch, D.H. 2015. Nutrient cycling and soil health in organic cropping systems- importance of management strategies and soil resilience. Sustainable Agriculture Research, Vol. 4, No. 3, pp. 80-86. https://doi.org/10.5539/sar.v4n3p80

12. Masilionytè, L., Maikštènienè, S. 2011. The effect of agronomic and meteorological factors on the yield of main and catch crops. Zemdirbyste-Agriculture, Vol. 98, No. 3, pp. 235-244.

13. Nemeikšienė, D., Arlauskienė, A., Šlepetienė, A., Cesevičienė, J., Maikštennienė, S. 2010. Mineral nitrogen content in the soil and winter wheat productivity as influnced by the pre-crop grasas species and their management. Žemdirbysté-Agriculture, Vol. 97 , No. 4, pp. 23-36.

14. Tarakanovas, P., Raudonius, S. 2003. Statistic analysis of agronomical research data with computer programs ANOVA, STAT, SPLIT-PLOT from packet selekcija and Irristat. Lithuanian University of Agriculture, 58 p. (In Lithuanian)

15. Thorup-Kristensen, K., Dresbøll, D.B., Kristensen, H.L. 2012. Crop yield, root growth, and nutrient dynamics in a conventional and three organic cropping systems with different levels of external inputs and $\mathrm{N}$ re-cycling through fertility building crops. European Journal of Agronomy, Vol. 37, Iss 1, pp. 66-82. https://doi.org/10.1016/j.eja.2011.11.004

16. Van der Burgt, G.J.H.M., Eekeren, N., Scholberg, J., Koopmans, C. 2013. Lucerne (Medicago sativa) or grass-clover as cut-andcarry fertilizers in organic agriculture. Grassland Science in Europe, Vol. 18, pp. 123-125.

17. Zotarelli, L., Zatorre, N.P., Boddey, R.M., Urquiaga, S., Jantalia C.P., Franchini, J.C., Alves, B.J.R. 2012. Influence of no-tillage and frequency of a green manure legume in crop rotations for balancing $\mathrm{N}$ outputs and preserving soil organic $\mathrm{C}$ stocks. Field Crops Research, Vol. 132, pp. 185-195. https://doi.org/10.1016/j.fcr.2011.12.013 